Int. J. Environ. Sci. Tech.

(C) Spring 2006, Vol. 3, No. 2, pp. 159-166

\title{
Microbiologically influenced corrosion in dairy effluent
}

\author{
"B. Ramesh Babu, S. Maruthamuthu, A. Rajasekar, N. Muthukumar and N. Palaniswamy
}

Central Electrochemical Research Institute, Karaikudi, India

Received 23 January 2006;

revised 3 March 2006;

accepted 15 March 2006;

available online 20 April 2006

\begin{abstract}
In the dairy industry mild steel is used as the construction material for the effluent treatment plants, pipelines, reinforcement in concrete structures etc. The steel exposed to the dairy effluent faces corrosion due to the microbes. In the present study the role of microbes in dairy effluent on the corrosion of mild steel has been investigated. Pseudomonas sp., Streptococcus sp., Micrococcus sp., Bacillus sp., Neisseria sp. and Lactobacillus sp. were identified in dairy effluent. Corrosion rate has been estimated by weight loss measurements and polarization technique. The Fourier transform infrared spectroscopy (FTIR) and X-ray diffractometer (XRD) studies were found helpful in investigating the chemical pathway leading to the formation of corrosion products on the mild steel during fermentation. Initiation of pitting corrosion was noticed on steel specimens by scanning electron microscope (SEM). A mechanism has been proposed for microbiologically influenced corrosion in dairy effluent.
\end{abstract}

Key words: Dairy effluent, Lactobacilli spp., Pseudomonas sp, fermentation, iron sulphide, microbiological corrosion

*Corresponding Author, E-mail: brbabu@cecri.res.in

\section{INTRODUCTION}

Microbiologically influenced corrosion (MIC) of mild steel in wastewater collection and treatment systems is well documented (Tatnall, 1981; Griffiths 1992). The microorganisms affect the corrosion process of the metal by directly influencing the anodic and cathodic reactions, by affecting protective surface films on metals, by producing corrosive substances and producing solid deposits. Various industries like chemical processing industries, nuclear power generation industries, water treatment industries and aviation industries have been affected by microbial corrosion, the most extensively studied microorganisms in relation to biocorrosion are the sulfate-reducing bacteria (SRB), whose participation in microbiologically influenced corrosion (MIC) was evidenced decades ago (Graves et al. 1996; Hamilton, 1985; Pope, et al., 1998; Voordouw et al., 1992; Von Wolzogen Kuhr et al., 1934). However aerobic manganese, iron oxidizing and acid producing bacteria and fungi may also participate in the corrosion process (Bento et al., 2001; Shennan, 1988; Videla et al., 1992). Microorganisms influence the corrosion by altering the chemistry at the interface between the metal and the bulk fluid (Jones et al., 2002; Little et al., 2002). Most of the equipment used for effluent treatment processes utilizes steel as a basic material of construction. Steel tanks and pipes are generally used to transport dairy effluent in liquid form from one place to another. Steel structures, tanks, pipes and components of the pipeline like steel valves; pipeline accessories exposed to diary effluent are affected by corrosion. Industrial effluents containing dissolved oxygen, suspended particles and the $\mathrm{pH}$ of the solution are the key factors that influence corrosion Gaylarde et al., 1999; Gaylarde, 1989; Buck, et al., 1996; Koch, et al., 2001; Birgitta, et al., 1999; Ternstrom et al., 1993; Kumar et al., 1998). In the present study an attempt has been made to investigate the effect of dairy effluent, collected from Aavin locally available milk processing company, on mild steel corrosion. Samples of dairy effluent were collected on 16th of December 2005 from a local dairy product company, Karaikudi located in Sivaganga district, Tamilnadu, India by using sterilized conical flasks. These samples were transported from the industry to the microbilogical laboratory, Central Electrochemical Research Institute, Karaikudi by using an icebox and the bacterial counts were enumerated within 24 hrs.

\section{MATERIALSAND METHODS}

Bacterial enumeration and identification in dairy effluent

Samples of dairy effluent were collected on $3^{\text {rd. }}$ week of December from a local dairy product company located in Sivaganga District, Tamilnadu, India by using sterilized conical flasks. Using an icebox from sites to CECRI, microbiological lab transported these samples. Karaikudi. The collected samples were serially diluted (10 fold) using $9 \mathrm{~mL}$ of sterile distilled water-blanks and the samples were 
plated by the pour plate technique. The nutrient agar medium, and lactobacillus medium(Hi-media, Mumbai) were used to enumerate heterotrophic bacteria and lactic acid producing bacteria respectively. The collected samples were further serially diluted up to $10^{-6}$ dilution. $1 \mathrm{~mL}$ of each sample was poured into sterile petridishes. The prepared respective sterile medium was also poured into petridishes. The plates were gently swirled so that the medium might be distributed evenly in the plate. Plates in triplicate were prepared for each dilution. The plates were incubated at room temperature for $24 \mathrm{~h}$. After $24 \mathrm{~h}$. to $48 \mathrm{~h}$. the colonies were counted. The plates containing bacterial colonies with 30-300 numbers were selected for calculation. The bacterial colonies were expressed as colony forming units per $\mathrm{mL}$ (CFU/mL). Morphologically dissimilar colonies were selected randomly from all plates and isolated colonies were purified using an appropriate medium by streaking methods. In the streaking method, one loopful of inoculam was placed on the medium near the rim of the plate and spread over a segment in a zigzag horizontal pattern until 1/3 of the plate is covered. The plate was rotated about 60 degrees and spread the bacteria from the first streak in to a second area using the same motion in zigzag horizontal pattern. The lid was replaced and inverted the plate. The plate was incubated at room temperature. The isolated pure cultures were maintained in test tubes as slant culture for further analysis. Six isolates were identified in the dairy effluent samples. The strains were maintained at $40^{\circ} \mathrm{C}$ to keep the microbial strain viable. The isolated bacterial cultures were identified up to genus level by their morphological and biochemical characterization according to the key described in Bergey's manual of determinative bacteriology (Holt et al., 1994).

\section{Corrosion studies}

Mild steel coupons ( $\left.1 \mathrm{x} 4 \mathrm{~cm}^{2}\right)$ were mechanically polished to mirror finish and then degreased using trichloroethylene. A known quantity of dairy effluent was taken in five beakers and coupons were immersed in the effluent and the weight loss values were collected for different periods (5, 10, 15, and 20 days). The effluent was kept at room temperature $\left(25-30^{\circ} \mathrm{C}\right)$ allowed to ferment and the $\mathrm{pH}$ was measured for periods of different duration $5,10,15$, and 20 days. After the different immersion periods, the coupons were removed, washed in distilled water and dried. Final weights of the steel coupons in each system were taken and the average corrosion rates calculated. The Tafel polarization curves were obtained by scanning the potential from the open circuit potential towards 200 $\mathrm{mV}$ anodically and cathodically. The scan rate was 120 $\mathrm{mV} / \mathrm{min}$. Polarization measurements were carried out potentiodynamically using model PGP201, employing potentiostat with volta master-1-software. A $1 \mathrm{~cm}^{2}$ mild steel coupon was used for the polarization studies. A saturated calomel electrode (SCE) was used as the reference electrode and a platinum wire as counter electrode. The $i_{\text {corr }}$ values were obtained from the plot of E Vs log I curve (Gunasekaran et al., 1997).

\section{Chemical characterization and surface analysis}

Chloride, sulphate, magnesium and calcium were estimated in the dairy effluent. Chloride was estimated by Mohr's method and sulphate was estimated by the gravimetric method. Magnesium and calcium present in the dairy effluent sample, were analyzed using atomic absorption spectroscopy (Varian AAS Model: Spectra 220). The biological oxygen demand (BOD) and chemical oxygen demand (COD) of the samples were determined using a BOD analyzer and titration methods respectively. Fourier Transform infrared spectroscopy (Make, Nicolet Nexus 470) was used for the analysis of the biochemical characteristics of the dairy effluent sample and also the biofilm collected from the metal exposed to the dairy effluent. The spectrum was taken in the mid IR region of $400-4000 / \mathrm{cm}$. The spectrum was recorded using the ATR (Attenuated Total Reflectance) technique. The sample was directly placed on the sample holder (zinc selenide crystal) and the spectrum recorded in the transmittance mode. The mild steel specimens were removed from the dairy effluent and the corrosion product was dried and crushed to a fine powder and used for X-ray diffraction spectroscope (XRD) analysis. A computer controlled XRD system, (JEOL Model JDX - 8030) was used to scan the corrosion products between $10^{\circ}$ and $85^{\circ}$ with copper $\mathrm{K} \alpha$ radiation (Ni filter) at a rating of $40 \mathrm{kV}, 20 \mathrm{~mA}$ to determine the nature of the film formed on the mild steel. After 20 days exposure the specimens were removed from the dairy effluent sample and examined for the nature of corrosion on the steel in a scanning electron microscope (SEM) Hitachi model S-3000H at a magnification ranging from $500 \mathrm{X}$ to $3000 \mathrm{X}$ and operated at an accelerating voltage of $25 \mathrm{kV}$.

\section{RESULTS}

Enumeration and identification of bacteria

The total viable bacterial activity of hetrotrophic bacteria (HB) is $7.2 \mathrm{X} 10^{14} \mathrm{CFU} / \mathrm{mL}$ while Lactobacilli (LB) is 4.7 
$\mathrm{X} 10^{8} \mathrm{CFU} / \mathrm{mL}$. Though several isolates have been identified in the effluent, only six predominant bacterial species were characterized up to generic level using standard biochemical characterization methods. The identified genus types are as follows: Pseudomonas spp. Streptococcus spp. Micrococcus spp., Bacillus spp. Neisseria spp. and Lactobacillus spp. It can be seen that out of the six genuses three are rod shaped while three are coccus shaped. Four are gram positive while two belong to gram-negative strains. Among six isolates, four have the ability to move from one place to other. The entire six genus have the ability to secrete the enzyme called oxidase, and to carryout carbohydrate fermentation. In addition, four genuses are able to reduce nitrate and five genuses have the ability to consume citrate. It can also be seen that the entire six genus can produce acid through the consumption of sugar, where as five strains have the ability to produce gas. Micrococcus is a chemoorganotroph with a respiratory metabolism often producing little or no acid from carbohydrates. Streptococcus is chemo an organotrph requiring nutritionally rich media for growth and $5 \%$ carbon dioxide. The cell metabolism is fermentative, producing lactate but no gas. Bacillus is a chemolithio organotroph with a fermentative or respiratory metabolism. Lactobacillus is also a chemoorganotroph, which requires rich complex media and metabolism is fermentative and saccharoclastic; at least half of the end product carbon is lactate. Niesseria is chemoorganotroph, which produces carbonic anhydrase. Pseudomonas is also chemolitho organotrophic, which is able to use hydrogen or carbon monoxide as an energy source.

\section{Corrosion studies}

The corrosion rate of mild steel obtained from the weight loss study is shown in Table 1 . The corrosion rates of mild steel were 0.040, 0.047, 0.048, 0.049 mmpy at 5, 10, 15 and 20 days respectively. Table 2 shows the corrosion current observed using the Tafel polarization method. The instantaneous corrosion current was found to be $0.51 \mu \mathrm{A} / \mathrm{cm}$ whereas on the second day the corrosion current was found to be $0.27 \mu \mathrm{A} / \mathrm{cm}$. After the

Table 1: Corrosion rate of mild steel by weight loss method

\begin{tabular}{cccc}
\hline Systems & $\begin{array}{c}\text { Immersion } \\
\text { Period (days) }\end{array}$ & $\begin{array}{c}\text { Weight loss } \\
(\mathrm{mg})\end{array}$ & $\begin{array}{c}\text { Corrosion rate } \\
\text { (mmpy) }\end{array}$ \\
\hline 1 & 5 & $14 \pm 2$ & 0.040 \\
2 & 10 & $33 \pm 3$ & 0.047 \\
3 & 15 & $50 \pm 2$ & 0.048 \\
4 & 20 & $69 \pm 3$ & 0.049 \\
\hline
\end{tabular}

$14^{\text {th. }}$ day the corrosion current was $5.00 \mu \mathrm{A} / \mathrm{cm}$, where as $9.72 \mu \mathrm{A} / \mathrm{cm}$ was observed on the $20^{\text {th. }}$ day (Fig. 1).

\section{Chemical characterization and surface analysis}

Table 3 shows the chemical analysis of the dairy effluent. It can be seen that the sulphate and chloride contents were 40 and 70 ppm respectively. The values of BOD and COD before and after corrosion were 25 ppm, 320 ppm and 9 ppm, 360 ppm respectively. pH values were in the range between 7.2 and 7.5. Fig. 2 shows the FTIR spectrum of dairy effluent over a period of 20 days. The FTIR spectrum shows a peak at $3317 / \mathrm{cm}$ indicates the presence of $\mathrm{OH}$ peak. The other peaks at $2918 / \mathrm{cm}$ and $2849 / \mathrm{cm}$ indicate the presence of $\mathrm{CH}$ aliphatic stretch. The carbonyl peak $(\mathrm{C}=\mathrm{O})$ in the range between $1722 / \mathrm{cm}$ and $1737 / \mathrm{cm}$ and $\mathrm{C}=\mathrm{C}$ conjugated diene at $1631 / \mathrm{cm}$ and $1657 / \mathrm{cm}$ are noticed. The Carboxylate ion ( $\left.\mathrm{COO}^{-}\right)$could be seen in the range between $1548 / \mathrm{cm}$ and $1480 / \mathrm{cm}$. The C-Cl bond is seen at about $626 / \mathrm{cm}$. Fig. 3 shows the FTIR spectrum of biofilm on mild steel immersed in dairy effluent. The IR spectrum analysis shows that the peaks at $3316 / \mathrm{cm}$ indicate the presence of $\mathrm{OH}$ bond. The other peaks in the range between $1754 / \mathrm{cm}$ and $1776 / \mathrm{cm}$ indicate the presence of the carbonyl group $(\mathrm{C}=\mathrm{O})$ and $\mathrm{C}=\mathrm{C}$ conjugated diene at $1632 / \mathrm{cm}$, carboxylate anion (COO-) at $1555 / \mathrm{cm}^{-}$and $1468 / \mathrm{cm}$. Another peak at $743 / \mathrm{cm}$ indicates the iron oxide bond and the peak at $626 / \mathrm{cm}$ indicates the carbon chloride (C-Cl) bond. The XRD pattern of corrosion product is shown in Fig. 4. A predominant iron sulphide peak could be noticed, indicating the role of microaerophilic in the conversion of sulphate to sulphide on steel corrosion. An SEM photograph shows the initiation of pitting on a mild steel coupon (Fig. 5).

\section{DISCUSSION AND CONCLUSION}

On the basis of biochemical characteristics of microbes it can be concluded that the abovementioned chemoorganotrophs utilize energy from dairy effluent and chemolithotrophs accelerates the corrosion process by converting ferros ion to ferric and its oxides (Muthukumar et al., 2003, Dawood et al., 1998, Jayaraman et al., 1998, Rajasekar et al., 2005). The corrosion rates of mild steel were $0.040,0.047$, $0.048,0.049 \mathrm{~mm} / \mathrm{y}$ at 5, 10, 15 and 20 days respectively. The corrosion current increased with time except on the second day while $b_{c}$ (cathodic tafel slope) values for the initial and on the second day were not 
Table 2: Corrosion rate of mild steel in dairy effluent by polarization technique

\begin{tabular}{ccccc}
\hline Immersion period (days) & $\mathrm{I}_{\text {corr }}\left(\mu \mathrm{A} \mathrm{cm}^{-2}\right)$ & $\begin{array}{c}\mathrm{b}_{\mathrm{a}} \mathrm{mV} \\
\text { decade }^{-1}\end{array}$ & $\begin{array}{c}\mathrm{b}_{\mathrm{c}} \mathrm{mV} \\
\text { decade }^{-1}\end{array}$ & $\begin{array}{c}\text { Corrosion rate } \\
(\mathrm{mmpy})\end{array}$ \\
\hline 0 & 0.51 & 164 & 157 & 0.006 \\
2 & 0.27 & 135 & 137 & 0.003 \\
14 & 5.01 & 189 & 614 & 0.059 \\
20 & 9.72 & 167 & 273 & 0.114 \\
\hline
\end{tabular}

Table 3: Chemical analysis of dairy effluent

\begin{tabular}{cc}
\hline Chemical characteristics & Concentration $(\mathrm{ppm})$ \\
\hline Sulphate & 40.0 \\
Chloride & 70.0 \\
Magnesium & 7.0 \\
Calcium & 56.0 \\
BOD & $25^{*}$ \\
COD & $320^{*}$ \\
\hline
\end{tabular}

After corrosion studies BOD is 9 ppm and COD is $360 \mathrm{ppm}$

significantly changed, but some significant change in $\mathrm{b}_{\mathrm{a}}$ (anodic tafel slope) value was noted. These data indicate that there is not much influence of cations on steel up to the $2^{\text {nd. }}$ day. On the $14^{\text {th. }}$ and $20^{\text {th. }}$ days both the curves (anodic and cathodic) were shifted to right and indicate a higher corrosion rate (Fig. 1). Itdemonstrates the influence of both anionic and cationic species on corrosion. It can be assumed that the presence of calcium and magnesium ions in the dairy effluent and the formation of ferric sulphide (cathodic to parent metal) during fermentation (decay), may influence the changes in the cathodic curves. The formation of hydrogen sulphide (HS-) ions in the dairy effluent may enhance the anodic reaction. Further the reduction of oxygen during fermentation also influences the cathodic reaction and accelerates the corrosion current. The values of BOD and
COD suggest that the decreasing of BOD may be due to the fermentation of dairy effluent. During decay (fermentation) the microbes present consume organic compounds, degrade the effluent, converting them in to organic acids with the creation of anaerobic environment. The metal immersed in dairy effluent FTIR shows a new peak at 743/cm which indicates the presence of a carbon chloride bond (Fig. 3). It may be due to the presence of chloride in the dairy effluent. CH aliphatic stretch (2918/ $\mathrm{cm}$ and $2849 / \mathrm{cm}$ ) could not be observed in biofilm on metal steel immersed in dairy effluent. It reveals that the carbon hydrogen bond is converted as carbon-chloride bond during the fermentation of dairy effluent. The XRD pattern indicates the presence of iron sulphide peaks on steel surface. It can be assumed that the assimilated sulphate conversion into sulphide by a micro aerophilic organism, namely Lactobacillus influences the corrosion rate. The sulphide combines with $\mathrm{Fe}^{2+}$ to form $\mathrm{FeS}$. The FeS may then combine with an organic molecule and influence the corrosion process both anodically and cathodically (Williams, 2004). The FTIR spectrum reveals the formation of carbon chloride compounds on the coupon during fermentation in the dairy effluent. It can be claimed that the adsorption of chloride ions and the formation of FeS is the causative factor for corrosion.

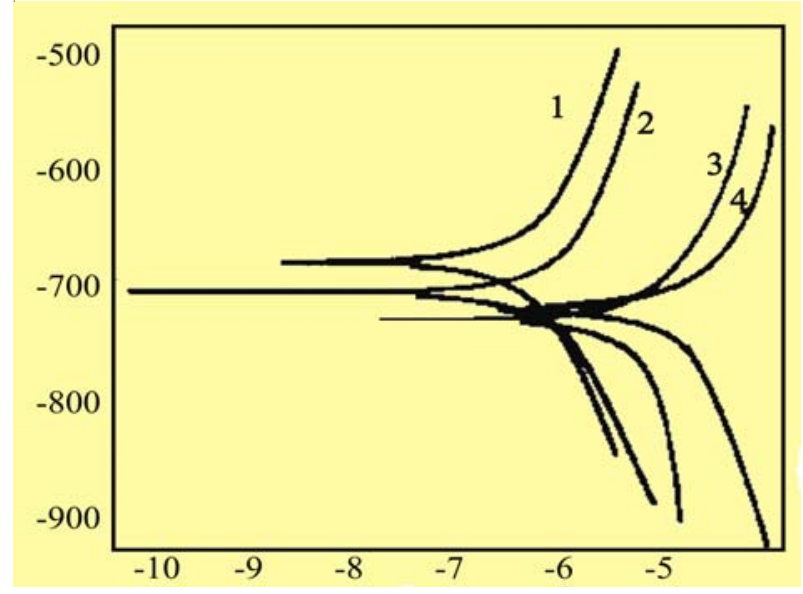

Fig 1. Polarization beaviour of mild steel in presence of dairy effluent at various periods. $1=0$ day, $2=1^{\text {st }}$ day, $3=14^{\text {th }}$ day, $4=20^{\text {th }}$ day 


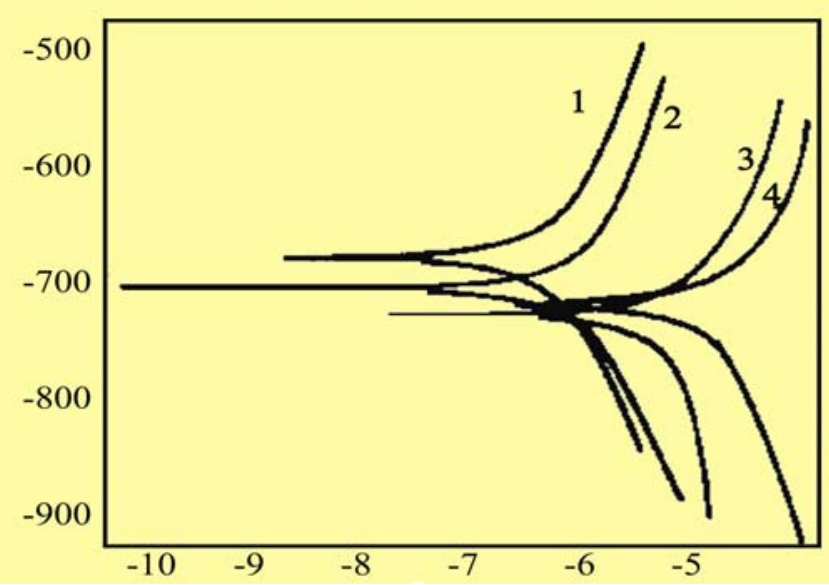

Fig. 2: FTIR spectrum of diary effluent

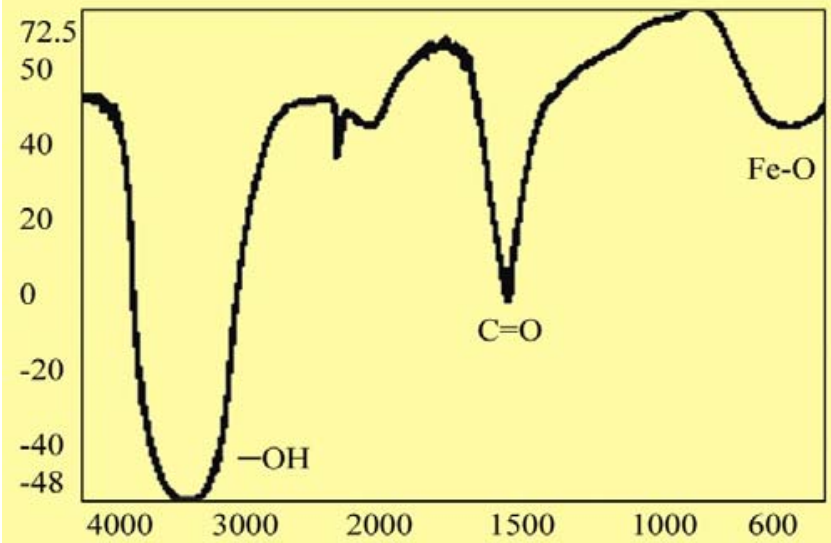

Fig. 3: FTIR spectrum of biofilm on mild steel immersed in dairy effluent

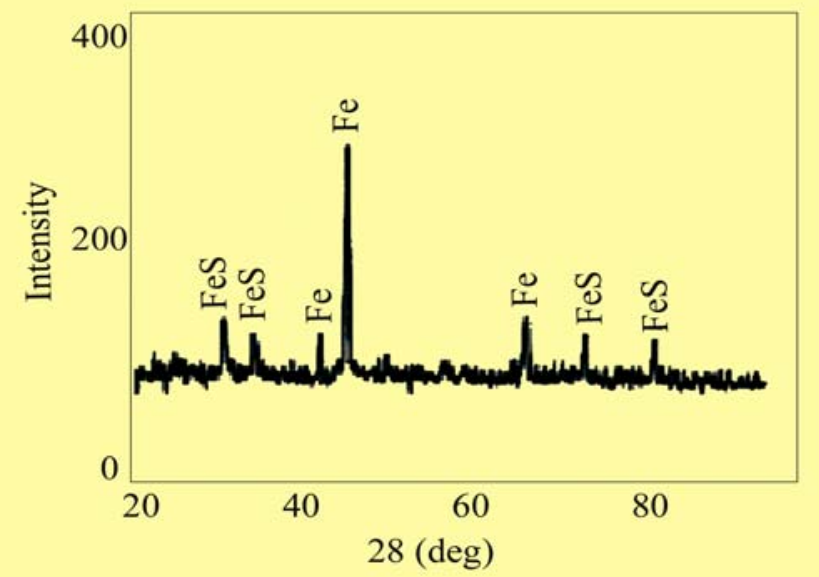

Fig. 4: XRD pattern of corrosion product on mild steel 
B. Ramesh Babu, et al.

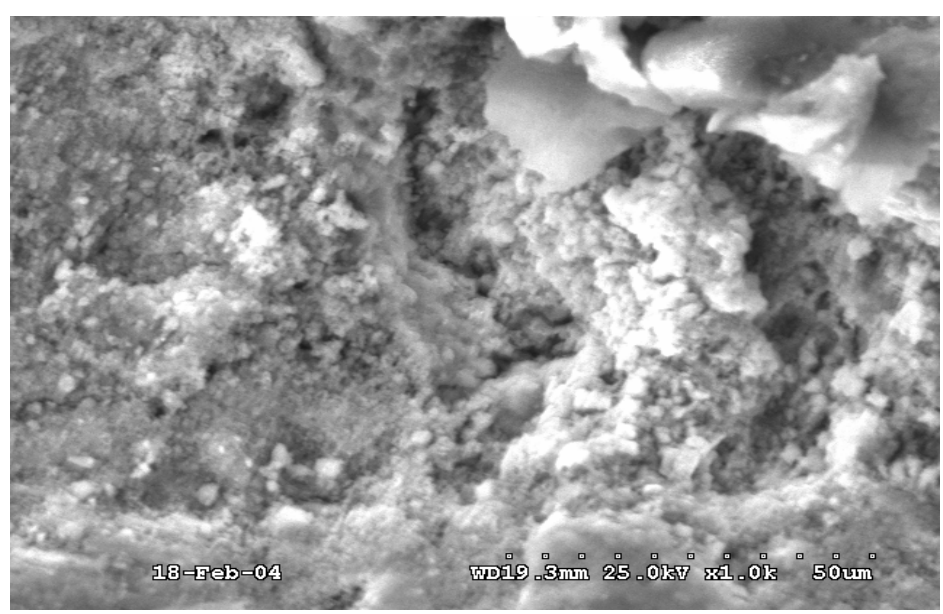

Fig. 5: SEM micrograph of mild steel after immersion in dairy effluent

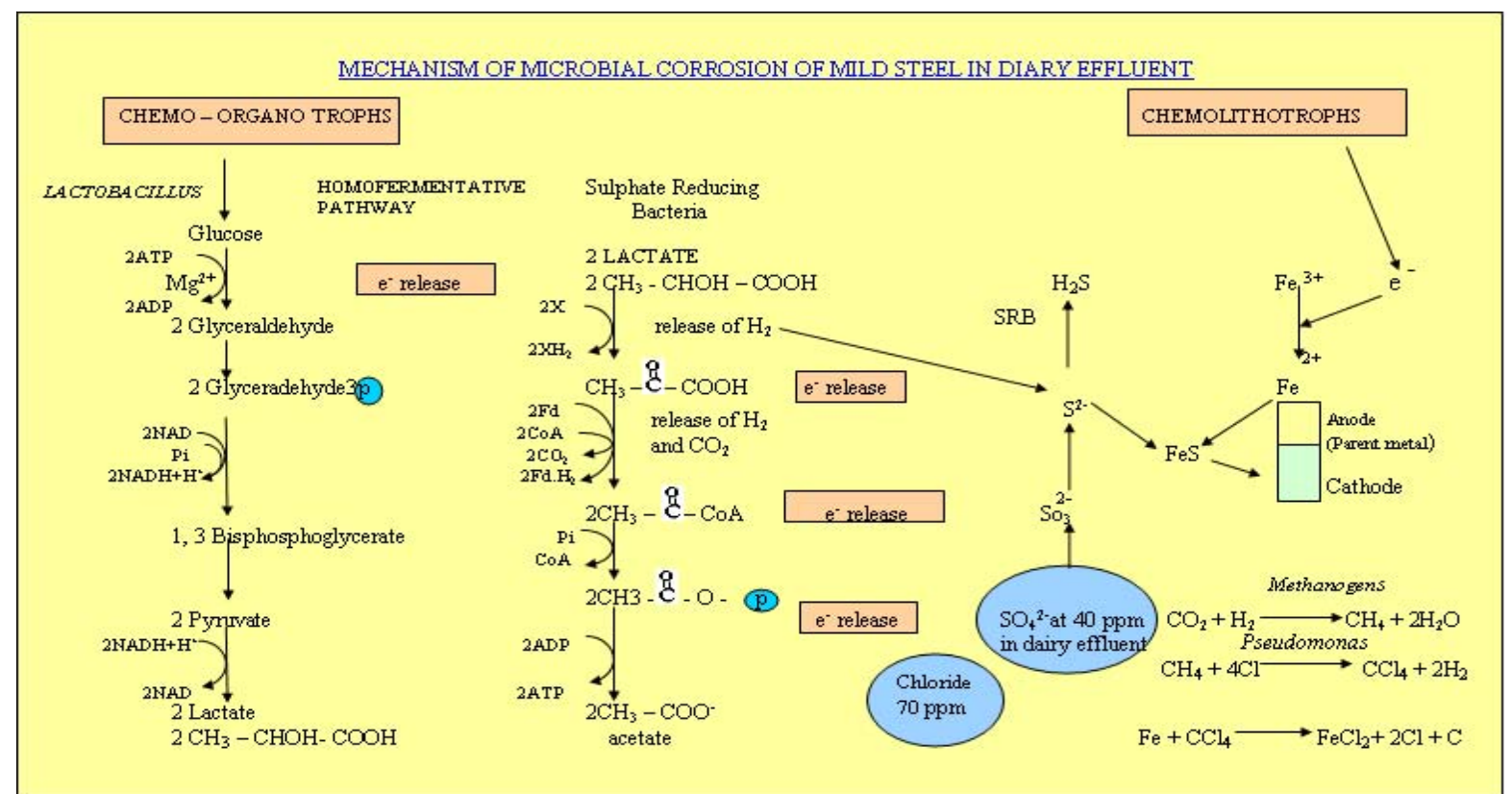

* The formed hydrogen and carbon are taken up by the chemolithotrophs and helps in the further reduction leading to the corrosion process.

Fig. 6: Corrosion model for mild steel in dairy effluent

The presence of FeS was noticed in the XRD studies. SEM studies also showed some pitting initiation in the coupon immersed in the dairy effluent. It can also be claimed that during the fermentation process bacteria consume oxygen from the metal surface $\left(\mathrm{O}_{2}\right.$ reduction) and take energy from the organic content in the dairy effluent. Subsequently the microbes convert sulphate into sulphide with the acceptance of electrons from the organic content (Sass and Cypionka, 2004) (Lactate- electron donor; sulphate-electron acceptor). Pseudomonas chemolithitrophic species may reduce ferric to ferrous (Weslake, 1986) and favour the formation of FeS. Hence sulphide formation has been noticed on the metal surface and FeS corrosion product appeared. It can be concluded that microbiologically influenced corrosion is responsible for corrosion of steel in dairy effluent and a possible mechanism has been explained in Fig. 6. The following 
observations have been made from the work reported in the present study

1. Bacillus, Pseudomonas, Micrococcus, Niesseria, Streptococcus and Lactobacillus were found in dairy effluent.

2. Corrosion rate was found to increase with time by weight loss measurements and the values of $\mathrm{I}_{\text {corr }}$ increases with time in polarisation technique.

3. It was clearly noted that the microbes influence the corrosion by oxygen reduction and fermentation processes.

4. The presence of sulphide ions on the mild steel coupon indicates that the microbes take energy from the organic content and convert sulphate into ferrous sulphide (FeS), which can act as cathode and the parental metal as anode.

5. An SEM study showed the initiation of pitting corrosion of mild steel.

\section{ACKNOWLEDGEMENT}

Authors thank the General Manager, Aavin processing company, Karaikudi, Tamilnadu for providing the dairy effluent.

\section{REFERENCES}

Bento, F. M. and Gaylarde, C. C., (2001). Biodetrioration of stored diesel oil: studies in Brazil. International. Biodeterioration. Biodegradation, 47, 107-112.

Buck, E., Maddux, G. C. and Sullivan, R. L., (1996). Intern corrosion cost impact study - United States natural gas expolarization and production industry. GRI-96/0056 document No 96-1466. Gas Research Institute Des Plaines.

Dawood, Z. and Brozel, V. S., (1998). Corrosion-enhancing potential of Shewanella putrefaciens isolated from industrial cooling waters. J. Appl. Microbiol., 84, 929-936.

Gaylarde, C. C., Bento, F. M. and Kelley., (1999). Microbial contamination of stored hydrocarbon fuels and its control mini-review Revista de Microbiologia, 30, 01-10.

Gaylarde, C. C., (1989). Microbial corrosion of metals. Environ. Engin., 30-32.

Graves, J. W. and Sullivan, E. H.,(1996). Internal corrosion in gas gathering systems and transmission lines. Material. Protection, 5, 33-37.

Griffiths, M. W., (1992). Bacillus cereus in liquid milk and other milk products. Bulletin. Inter. Dairy Federation, 275, 36-39.

Gunasekaran, G., Palanisamy, N., Appa Rao, B. V. and Muralidharan V. S., (1997). Synergistic inhibition in low chloride media, Electrochim. Acta., 42, 1427-1434.

Hamilton, W. A., (1985). Sulphate-reducing bacteria and anaerobic corrosion. Annual. Review. Microbiol, 39 ,195217.
Holt, J. G., Kreig, N. R., Sneath, P. H. A. and Stanely, J. T., (1994). In: Bergey's manual of Determinative Bacteriology, Williams, S.T, (Eds.) Williams and Wilkins Publishers Maryland.

Jayaraman, A., Sun, A. K. and Wood, T. K., (1998). Characterization of axenic Pseudomonas fragi and Escherichia coli biofilms that inhibit corrosion of SAE 1018 steel. J. App. Microbiol. 84, 485-492.

Jones, D. A. and Amy, P. S., (2002). A thermodynamic interpretation of microbiologically influenced corrosion. Corrosion, 58, 638-645.

Kumar, C. G. and Anand, S. K., (1998). Significance of microbial biofilms in food industry: a review. International. J. Food Microbiol., 42, 9-27.

Koch, G. H., Brongers, M. P. H., Thompson, N. G., Virmani, Y. $\mathrm{P}$ and Payer, J. H., (2001). Corrosion costs and preservative strategies in the United States FHWA-RD-01-156. (online) Fedral Highway Administration, Wasington, D.C.

Little, B. and Ray, R., (2002). A perspective on corrosion inhibition by biofilms. Corrosion, 58, 424-428. 431.

Muthukumar, N., Rajasekar, A., Ponmarriappan, S., Mohanan, S., Maruthamuthu, S, Muralidharan, S., Subramanian, P., Palaniswamy N. and Raghavan, M., (2003). Microbiologically influenced corrosion in petroleum product pipelines- a review. Indian. J Experimen. Bio., 41, 10121022.

Pope, D. H. and Pope, R. M., (1998). Guide for the monitoring and treatment of microbiologically influenced corrosion in the natural gas industry. GRI report GRI-96/0488. Gas Research Institute, Des Plaines, Ill. 445.

Rajasekar, A, Maruthamuthu, S., Muthukumar, N., Mohanan, S, Subramanian, P. and Palaniswamy, N. (2005). Bacterial degradation of naphtha and its influence on corrosion. Corro. Sci., 47, 251- 271.

Sass, H. and Cypionka, H., (2004). Isolation of SulfateReducing Bacteria from the Terrestrial Deep Subsurface and Description of Desulfovibrio cavernae sp. nov. System. App. Microbiol., 27, 541-548.

Svensson, B., Eneroth, A., Brendehaug, J. and Christiansson, A., (1999). Investigation of Bacillus cereus contamination sites in a dairy plant with RAPD-PCR Inter. Dairy J., 9, 903-912.

Shennan, J. L., (1988). Control of microbial contamination of fuels in storage. 248-254. In D.R. Houghton, R.N. Smith, and H.O.W. Eggins (ed.), Biodeterioration, Elsevier, Barking, 452.

Tatnall, R. E., (1981). Corrosion 81 NACE, Houston, TX.

Ternstrom, A, Lindberg, A. M. and Molin, G., (1993). Classification of the spoilage flora of raw and pasteurized bovine milk, with special reference to Pseudomonas and Bacillus. J. Appl. Bacterio., 75, 25-34.

Von Wolzogen Kuhr, C. A. H. and Vander Klugt Walker, I. S. (1934). The graphitization of cat iron as an electrochemical process in anaerobic solid. Water, 18, 147-165.

Voordouw, G., Voordouw, J. K., Jack, T. R., Foght, J. Fedorak, P. M. and Westlake, D. W. S., (1992). Identification of distinct communities of sulfate reducing bacteria in oil fields by reverse sample genome probing. Appl Environ. Microbiol., 58, 3542-3552. 
Videla, H. A. and Characklis, W. G., (1992). Biofouling and microbially influenced corrosion. Inter,. Biodeteri. Biodegra., 29, 195-212.

Weslake, D. W. S. and Obeuke, C. O., (1986). Corrosion by ferric iron reducing bacteria isolated from oil production systems in Dexter S. C (Eds.). Biologically induced corrosion, NACE Houston, TX, 193-200.
Williams, M. M., Domingo, J. W. S., Meckes, M. C., Kelty, C. A. and Rochon, H. S. (2004). Phylogenetic diversity of drinking water bacteria in a distribution system simulator. J. App. Microbiol., 96, 954-964.

\section{AUTHOR(S) BIOSKETCHES}

Ramesh Babu, B., B.E., P.G.D.C.A., Ph.D., is a scientist in the Department of Pollution Control, Central Electrochemical Research Institute, Karaikudi, India.

E-mail:brbabu@cecri.res.in

Maruthmuthu, S., M.Sc., M.Phil., Ph.D., is a scientist in the Department of Biocorrosion Group, Corrosion Science and Engineering Division, Central Electrochemical Research Institute, Karaikudi, India. E-mail: biocorr@cecri.res.in

Rajasekar, A., M.Sc., is a senior research fellow in the Department of Biocorrosion Group, Corrosion Science and Engineering Division, Central Electrochemical Research Institute, Karaikudi, India. Email:raja76sekar@rediffmail.com

Muthukumar, N., M.Sc., M.Phil., is a senior research fellow in the Department of Biocorrosion Group, Corrosion Science and Engineering Division, Central Electrochemical Research Insititute, Karaikudi, India.E-mail: raja76sekar@rediffmail.com

Palaniswamy, N., M.Sc., Ph.D., is a Deputy Director, Head, Corrosion Science and Engineering Division, Central Electrochemical Research Insititute, Karaikudi, India.

E-mail:swamy23@rediffmail.com

This article should be referenced as follows:

Ramesh Babu, B., Maruthmuthu, S., Rajasekar, A.,Muthukumar, N., Muthukumar, N. and Palaniswamy, N., (2006). Microbiologically influenced corrosion in dairy effluent. Int. J. Environ. Sci. Tech., 3 (2), 159-166. 